\title{
The Power and Wisdom of Prevention. Cardiovascular Risk, New Challenge and Approach to PLWH
}

\author{
Ricardo Massmann*1, David Jilich ${ }^{2}$, Lukáš Fleischhanss ${ }^{1}$, Marek Malý ${ }^{3}$ and Ladislav Machala ${ }^{4}$ \\ ${ }^{1}$ Department of Infectious and Tropical Diseases, Third Faculty of Medicine, Charles University and Na Bulovce Hospital, Prague, \\ Czech Republic
}

${ }^{2}$ Department of Infectious and Tropical Diseases, First Faculty of Medicine, Charles University and Na Bulovce Hospital, Prague, Czech Republic

${ }^{3}$ Department of Biostatistics, National Institute of Public Health, Prague, Czech Republic

${ }^{4}$ Department of Infectious Diseases, Third Faculty of Medicine, Charles University and Na Bulovce Hospital, Prague, Czech Republic and Director from HIV/AIDS Center - Department of Infectious Disease, Bulovka University Hospital, Prague

*Corresponding author: Ricardo Massmann, Department of Infectious and Tropical Diseases, Third Faculty of Medicine, Charles University and Na Bulovce Hospital, Prague, Czech Republic

\section{ARTICLE INFO}

Received: May 18, 2021

Published: 絊 May 28, 2021

Citation: Ricardo Massmann, David Jilich, Lukáš Fleischhans, Marek Malý, Ladislav Machala. Cardiovascular Risk, New Challenge and Approach to PLWH. Biomed J Sci \& Tech Res 36(1)-2021. BJSTR. MS.ID.005808.

Keywords: Human Immunodeficiency Virus (HIV); Antiretroviral Therapy (ART); Cardiovascular Disease (CVD); Atherosclerosis

\section{ABSTRACT}

In recent years, quality of life is one of the important points of discussion among specialists working with people living with HIV (PLWH). With the introduction of highly effective antiretroviral therapy (1996), the expectation of life has dramatically increased, and atherosclerotic diseases have become an important cause of morbidity and mortality in people infected with human immunodeficiency virus (HIV). Cardiovascular diseases are the third leading cause of mortality in HIV patients behind non-AIDS-related malignancies and non -AIDS-related infection. One of the many aspects in the treatment of PLWH concerns the prevention of cardiovascular diseases. The absolute risk of developing major cardiovascular disease events (CVD), for example, sudden cardiac death, cardiac arrest, and stroke in HIV-infected patients receiving antiretroviral therapy is still low. However, this risk is increased compared to the risk of uninfected people. This fact is substantially due to a higher prevalence of traditional cardiovascular risk factors that are mostly dependent on the host. Different types of antiretroviral treatment impact differently on metabolic effects and CVD. Prevention of cardiovascular disease in HIV-infected patients is an important goal for a better quality of life. Traditional risk factors should be detected and treated vigorously when possible, to avoid the development of major adverse cardiac events (MACE).

Abbreviations: HIV: Human Immunodeficiency Virus; PLWH: People Living with HIV; CVD: Cardiovascular Disease; MACE: Major Adverse Cardiac Events; NCDs: Non-Communicable Diseases; ART: Antiretroviral Therapy; PIs: Protease Inhibitors; FRS: Framingham Risk Score; ASCVD: Atherosclerotic CVD; SCORE: Systematic Coronary Risk Evaluation; PROCAM: Prospective Cardiovascular Münster; IDV: Indinavir; LPV: Lopinavir; ABC: Abacavir; sICAM-1: Soluble Intercellular Adhesion Molecule-1; sVCAM-1: Soluble Vascular Cell Adhesion Molecule-1; vWF: von Willebrand Factor; IL: Interleukin; sTM: Soluble Thrombomodulin; SMART: Strategies for Management of Antiretroviral Therapy; TNF- $\alpha$ : Tumor Necrosis Factor Alpha; NRTI: Nucleoside Analog Reverse Transcriptase Inhibitors 


\section{Introduction}

The reduction in mortality in PLWH has transformed HIV into a long-term chronic illness for many patients, characterized by an ageing HIV-infected population who are increasingly affected by age-related non-communicable diseases (NCDs). Background combination antiretroviral therapy (ART) has significantly increased survival among HIV-positive adults, has dramatically reduced mortality and improved the quality of life of HIV-infected patients. Although the survival rate of the HIV-infected patient is generally lower than that of the non-HIV population [1]. Survival rates are estimated to overlap with the general population when the patient has been on antiretroviral therapy for more than 5 years with immunologic recovery. Cardiovascular diseases are the third leading cause of mortality in HIV patients behind non-AIDS related malignancies (11.8\%) and non -AIDS- related infection (8.2\%) [2]. For this reason, cardiovascular diseases and preventive medicine have become a focus in PLWH [3]. Initially the introduction of protease inhibitors (PIs) was associated with hyperlipidemia and consequently even higher risk of major cardiovascular events [4]. However, the risk of CVD, including acute myocardial infarction [5], sudden cardiac death [6], stroke [7], heart failure [8] and peripheral arterial disease [9], remains significantly higher than in the general population, and cannot be explained by PIs alone [10].
Some studies show a higher prevalence of cardiovascular risk factors, such as hypertension, cigarette smoking [11], metabolic syndrome [12], diabetes [13], dyslipidemia [14], and depression [15] in HIV-infected individuals compared with uninfected individuals. However, other studies have found no significant differences between the two populations. These discrepancies may be related to methodological aspects or the low prevalence of cardiovascular risk factors in HIV-infected patients included in the studies. In recent years, the scientific community has debated the specific weight of each of the factors involved in this increased risk, seeking to reduce the effect of antiretroviral therapy on HIV infection and on host-dependent factors. The distribution of HIV is very different depending on the geographic area. The economic and social situation also plays an important role. In Europe the situation is different from the reality in sub-Saharan Africa, Latin America or Asia. In the last decade, the number of infections has remained stable in Europe, while in Asia, Latin America and Eastern Europe the percentage of infections has increased. Access to ART and the quality of health services differ according to geographical areas. Different dietary, urban and social habits will play an important role in the development of cardiovascular diseases. Our understanding of this question is more developed for Europe [16] and the USA, thanks to the majority of research. An overview and summery of the most important studies is shown in (Table 1).

Table 1.

\begin{tabular}{|c|c|c|c|c|c|c|c|c|}
\hline \multicolumn{9}{|c|}{ Studies on the Association of HIV Status and Clinical Cardiovascular Disease } \\
\hline & Location & $\begin{array}{c}\text { N. of } \\
\text { Participants }\end{array}$ & $\begin{array}{l}\text { N. of HIV } \\
\text { Cases }\end{array}$ & $\begin{array}{l}\text { N. of CVD } \\
\text { Events }\end{array}$ & $\begin{array}{l}\text { Mean Age } \\
\text { (SD) }\end{array}$ & Outcome & $\begin{array}{l}\text { Measure of } \\
\text { Effect }\end{array}$ & $\begin{array}{c}\text { Effect } \\
\text { Estimate } \\
(95 \% \mathrm{CI})\end{array}$ \\
\hline \multicolumn{9}{|c|}{ Stroke } \\
\hline $\begin{array}{l}\text { Qureshi, et al. } \\
\text { (1997) }\end{array}$ & $\begin{array}{l}\text { Grady Memorial } \\
\text { Hospital, USA }\end{array}$ & 236 & 113 & 68 & $36(6)$ & $\begin{array}{l}\text { Cerebral } \\
\text { infarction }\end{array}$ & Odds ratio & $3 \cdot 2(1 \cdot 1-8 \cdot 9)$ \\
\hline $\begin{array}{l}\text { Cole, et al. } \\
\text { (2004) }\end{array}$ & $\begin{array}{c}\text { Baltimore- } \\
\text { Washington } \\
\text { Cooperative Young } \\
\text { Stroke Study, USA }\end{array}$ & 386 & 6 & 386 & 36 & $\begin{array}{l}\text { Ischemic } \\
\text { stroke }\end{array}$ & Odds ratio & $\begin{array}{l}13 \cdot 70(6 \cdot 10- \\
30 \cdot 80)\end{array}$ \\
\hline $\begin{array}{c}\text { Chow, et al. } \\
\text { (2012) }\end{array}$ & $\begin{array}{c}\text { Massachusetts } \\
\text { General Hospital } \\
\text { and Brigham and } \\
\text { Women's Hospital, } \\
\text { USA }\end{array}$ & 36731 & 4308 & 914 & $41(12)$ & $\begin{array}{l}\text { Ischemic } \\
\text { stroke }\end{array}$ & Hazard ratio & $\begin{array}{c}1 \cdot 21(1 \cdot 01- \\
1 \cdot 46)\end{array}$ \\
\hline $\begin{array}{l}\text { Mateen, et al. } \\
\text { (2013) }\end{array}$ & $\begin{array}{l}\text { Multicenter AIDS } \\
\text { Cohort Study, USA }\end{array}$ & 3945 & 1776 & 114 & 42 & All stroke & Relativ risk & $\begin{array}{c}2 \cdot 16(1 \cdot 39- \\
3 \cdot 31)\end{array}$ \\
\hline $\begin{array}{l}\text { Walker, et al. } \\
\text { (2013) }\end{array}$ & $\begin{array}{l}\text { Rural Hai district in } \\
\text { northern Tanzania } \\
\text { and urban Dar-es- } \\
\text { Salaam, Tanzania }\end{array}$ & 201 & 25 & 201 & $61(13)$ & All stroke & Odds ratio & $\begin{array}{c}5 \cdot 61(2 \cdot 41- \\
13 \cdot 09)\end{array}$ \\
\hline $\begin{array}{l}\text { Marcus, et al. } \\
\quad(2014)\end{array}$ & $\begin{array}{l}\text { Kaiser Permanente } \\
\text { Southern California } \\
\text { and Northern } \\
\text { California, USA }\end{array}$ & 282368 & 24768 & 1279 & $40(10)$ & $\begin{array}{l}\text { Ischemic } \\
\text { stroke }\end{array}$ & $\begin{array}{l}\text { Incidence rate } \\
\text { ratio }\end{array}$ & $1 \cdot 4(1 \cdot 2-1 \cdot 7)$ \\
\hline $\begin{array}{l}\text { Rasmussen, et } \\
\text { al. (2015) }\end{array}$ & $\begin{array}{l}\text { Danish HIV Cohort } \\
\text { Study }\end{array}$ & 58970 & 5897 & 1785 & 37 & Stroke & $\begin{array}{l}\text { Incidence rate } \\
\text { ratio }\end{array}$ & $\begin{array}{c}1 \cdot 84(1 \cdot 60- \\
2 \cdot 13)\end{array}$ \\
\hline $\begin{array}{l}\text { Sico, et al. } \\
\text { (2015) }\end{array}$ & $\begin{array}{c}\text { Veterans Aging Cohort } \\
\text { Study, USA }\end{array}$ & 76835 & 25434 & 910 & $49(9)$ & $\begin{array}{l}\text { Ischemic } \\
\text { stroke }\end{array}$ & Hazard ratio & $\begin{array}{c}1 \cdot 17(1 \cdot 01- \\
1 \cdot 36)\end{array}$ \\
\hline
\end{tabular}




\begin{tabular}{|c|c|c|c|c|c|c|c|c|}
\hline $\begin{array}{l}\text { Benjamin, et } \\
\text { al. (2016) }\end{array}$ & $\begin{array}{l}\text { Malawi urban } \\
\text { hospital; stroke cases } \\
\text { and community } \\
\text { controls }\end{array}$ & 725 & 69 & 222 & 59 & All stroke & Odds ratio & $\begin{array}{c}3 \cdot 28(2 \cdot 05- \\
5 \cdot 25)\end{array}$ \\
\hline $\begin{array}{l}\text { Alonso, et al. } \\
\text { (2019) }\end{array}$ & $\begin{array}{c}\text { Truven Health } \\
\text { MarketScan } \\
\text { Commercial Claims } \\
\text { and Encounter } \\
\text { and the Medicare } \\
\text { Supplemental and } \\
\text { Coordination of } \\
\text { Benefits databases, } \\
\text { USA }\end{array}$ & 79100 & 19798 & 93 & $43(13)$ & Stroke & Hazard ratio & $2 \cdot 3(1 \cdot 5-3 \cdot 6)$ \\
\hline \multicolumn{9}{|c|}{ Myocardial Infarction } \\
\hline $\begin{array}{l}\text { Triant, et al. } \\
\text { (2009) }\end{array}$ & $\begin{array}{c}\text { Massachusetts } \\
\text { General Hospital } \\
\text { and Brigham and } \\
\text { Women's Hospital, } \\
\text { USA }\end{array}$ & 70,357 & 487 & & Mid-50s & $\begin{array}{c}\text { Acute } \\
\text { myocardial } \\
\text { infarction }\end{array}$ & Odds ratio & $\begin{array}{c}1 \cdot 93(1 \cdot 21- \\
2 \cdot 93)\end{array}$ \\
\hline $\begin{array}{l}\text { Lang, et al. } \\
\text { (2010) }\end{array}$ & $\begin{array}{l}\text { French hospital } \\
\text { database on HIV }\end{array}$ & 74,958 & 74,958 & 360 & Not provided & $\begin{array}{l}\text { Myocardial } \\
\text { infarction }\end{array}$ & $\begin{array}{l}\text { Standardized } \\
\text { morbidity } \\
\text { ratio }\end{array}$ & $\begin{array}{c}1 \cdot 5(1 \cdot 3-1 \cdot 7) \\
\text { men; } 1 \cdot 4(1 \cdot 3- \\
1 \cdot 6) \text { women }\end{array}$ \\
\hline $\begin{array}{l}\text { Durand, et al. } \\
\text { (2011) }\end{array}$ & $\begin{array}{l}\text { Régie de l’Assurance } \\
\text { maladie du Québec, } \\
\text { Canada }\end{array}$ & 27,734 & 7053 & 365 & $40(11)$ & $\begin{array}{c}\text { Acute } \\
\text { myocardial } \\
\text { infarction }\end{array}$ & Hazard ratio & $\begin{array}{c}2 \cdot 11(1 \cdot 69- \\
2 \cdot 63)\end{array}$ \\
\hline $\begin{array}{l}\text { Klein, et al. } \\
\text { (2015) }\end{array}$ & $\begin{array}{c}\text { Kaiser Permanente } \\
\text { Southern California } \\
\text { and Northern } \\
\text { California, USA }\end{array}$ & 282,368 & 24,768 & 2803 & 40 & $\begin{array}{l}\text { Myocardial } \\
\text { infarction }\end{array}$ & $\begin{array}{l}\text { Incidence rate } \\
\text { ratio }\end{array}$ & $\begin{array}{c}1 \cdot 40(1 \cdot 20- \\
1 \cdot 60)\end{array}$ \\
\hline $\begin{array}{l}\text { Althoff, et al. } \\
\text { (2015) }\end{array}$ & $\begin{array}{c}\text { Veterans Aging Cohort } \\
\text { Study, USA }\end{array}$ & 83,527 & 56,274 & 689 & Mid-50s & $\begin{array}{c}\text { Acute } \\
\text { myocardial } \\
\text { infarction }\end{array}$ & Hazard ratio & $\begin{array}{c}1 \cdot 76(1 \cdot 49- \\
2 \cdot 07)\end{array}$ \\
\hline $\begin{array}{l}\text { Rasmussen, et } \\
\text { al. (2015) }\end{array}$ & Danish HIV cohort & 58,970 & 5897 & 1238 & $\begin{array}{c}\text { Median } 37 \\
\text { (IQR 31-44) }\end{array}$ & $\begin{array}{l}\text { Myocardial } \\
\text { infarction }\end{array}$ & $\begin{array}{l}\text { Incidence rate } \\
\text { ratio }\end{array}$ & $\begin{array}{c}2 \cdot 02(1 \cdot 71- \\
2 \cdot 38)\end{array}$ \\
\hline $\begin{array}{l}\text { Alonso, et al. } \\
\text { (2019) }\end{array}$ & $\begin{array}{c}\text { Truven Health } \\
\text { MarketScan } \\
\text { Commercial Claims } \\
\text { and Encounter } \\
\text { and Medicare } \\
\text { Supplemental and } \\
\text { Coordination of } \\
\text { Benefits databases, } \\
\text { USA }\end{array}$ & 79,100 & 19,798 & 154 & $43(13)$ & $\begin{array}{l}\text { Myocardial } \\
\text { infarction }\end{array}$ & Hazard ratio & $1 \cdot 2(0 \cdot 8-1 \cdot 8)$ \\
\hline \multicolumn{9}{|c|}{ Heart Failure } \\
\hline $\begin{array}{l}\text { Freiberg, et al. } \\
\qquad(2017)\end{array}$ & $\begin{array}{c}\text { Veterans Aging Cohort } \\
\text { Study, USA }\end{array}$ & 98,015 & 31,523 & 2636 & $48(10)$ & $\begin{array}{c}\text { Congestive } \\
\text { heart failure }\end{array}$ & Hazard ratio & $\begin{array}{c}1 \cdot 41(1 \cdot 29- \\
1 \cdot 54)\end{array}$ \\
\hline $\begin{array}{l}\text { Feinstein, et } \\
\text { al. (2018) }\end{array}$ & $\begin{array}{l}\text { HIV Electronic } \\
\text { Comprehensive } \\
\text { Cohort of CVD } \\
\text { Complications } \\
\text { (Northwestern } \\
\text { Medicine), USA }\end{array}$ & 7371 & 4640 & 152 & $40(11)$ & $\begin{array}{l}\text { Adjudicated } \\
\text { heart failure }\end{array}$ & Hazard ratio & $\begin{array}{c}2 \cdot 10(1 \cdot 38- \\
3 \cdot 21)\end{array}$ \\
\hline $\begin{array}{l}\text { Alonso, et al. } \\
\text { (2019) }\end{array}$ & $\begin{array}{c}\text { Truven Health } \\
\text { MarketScan } \\
\text { Commercial Claims } \\
\text { and Encounter } \\
\text { and Medicare } \\
\text { Supplemental and } \\
\text { Coordination of } \\
\text { Benefits databases, } \\
\text { USA }\end{array}$ & 79,100 & 19,798 & 223 & $43(13)$ & Heart failure & Hazard ratio & $2 \cdot 8(2 \cdot 0-3 \cdot 8)$ \\
\hline
\end{tabular}




\begin{tabular}{|c|c|c|c|c|c|c|c|c|}
\hline \multicolumn{9}{|c|}{ Peripheral Artery Disease } \\
\hline $\begin{array}{l}\text { Alonso, et al. } \\
\text { (2019) }\end{array}$ & $\begin{array}{c}\text { Truven Health } \\
\text { MarketScan } \\
\text { Commercial Claims } \\
\text { and Encounter } \\
\text { and Medicare } \\
\text { Supplemental and } \\
\text { Coordination of } \\
\text { Benefits databases, } \\
\text { USA }\end{array}$ & 79,100 & 19,798 & 98 & $43(13)$ & $\begin{array}{l}\text { Peripheral } \\
\text { artery disease }\end{array}$ & Hazard ratio & $0.9(0 \cdot 5-1 \cdot 4)$ \\
\hline $\begin{array}{l}\text { Beckman, et } \\
\text { al. (2019) }\end{array}$ & $\begin{array}{c}\text { Veterans Aging Cohort } \\
\text { Study, USA }\end{array}$ & 91,953 & 28,714 & 7708 & $48(10)$ & $\begin{array}{l}\text { Peripheral } \\
\text { artery disease }\end{array}$ & Hazard ratio & $\begin{array}{c}1 \cdot 19(1 \cdot 13- \\
1 \cdot 25)\end{array}$ \\
\hline $\begin{array}{l}\text { Lai, et al. } \\
\text { (2018) }\end{array}$ & $\begin{array}{c}\text { Taiwan Centers for } \\
\text { Disease Control, HIV } \\
\text { Surveillance Database }\end{array}$ & $2,000,000$ & 26,272 & 55 & $32(10)$ & $\begin{array}{l}\text { Peripheral } \\
\text { artery disease }\end{array}$ & $\begin{array}{l}\text { Standardized } \\
\text { Incidence rate }\end{array}$ & $\begin{array}{c}0 \cdot 87(0 \cdot 65- \\
1 \cdot 13)\end{array}$ \\
\hline \multicolumn{9}{|c|}{ Sudden Cardiac Death } \\
\hline $\begin{array}{l}\text { Tseng, et al. } \\
\text { (2012) }\end{array}$ & & 2860 & 2860 & 30 & $\begin{array}{l}\text { Median 39 } \\
\text { (IQR 33-45) }\end{array}$ & $\begin{array}{c}\text { Sudden } \\
\text { cardiac death }\end{array}$ & $\begin{array}{l}\text { Standardized } \\
\text { mortality ratio }\end{array}$ & $4 \cdot 46$ \\
\hline $\begin{array}{l}\text { Lai, et al. } \\
\text { (2018) }\end{array}$ & $\begin{array}{l}\text { Taiwan Centers for } \\
\text { Disease Control, HIV } \\
\text { Surveillance Database }\end{array}$ & $\begin{array}{l}\text { General } \\
\text { population }\end{array}$ & 26272 & 82 & & $\begin{array}{c}\text { Sudden } \\
\text { cardiac death }\end{array}$ & $\begin{array}{l}\text { Standardized } \\
\text { Incidence rate }\end{array}$ & $\begin{array}{c}3 \cdot 01(2 \cdot 39- \\
3 \cdot 73)\end{array}$ \\
\hline $\begin{array}{l}\text { Alvi, et al. } \\
\text { (2019) }\end{array}$ & $\begin{array}{l}\text { Bronx Lebanon } \\
\text { Hospital Center, Icahn } \\
\text { School of Medicine at } \\
\text { Mount Sinai, USA }\end{array}$ & 2149 & 344 & 191 & $60(9)$ & $\begin{array}{c}\text { Sudden } \\
\text { cardiac death }\end{array}$ & Odds ratio & $\begin{array}{c}3 \cdot 0(1 \cdot 78- \\
4 \cdot 24)\end{array}$ \\
\hline $\begin{array}{l}\text { Tseng, et al. } \\
\text { (CROI 2019, } \\
\text { unpublished) }\end{array}$ & $\begin{array}{l}\text { HIV specialty clinic } \\
\text { in San Francisco, } \\
\text { California, USA }\end{array}$ & 552 & 47 & 552 & $51-63$ & $\begin{array}{l}\text { Sudden } \\
\text { cardiac death }\end{array}$ & $\begin{array}{l}\text { Incidence rate } \\
\text { ratio }\end{array}$ & $\begin{array}{c}1 \cdot 86(1 \cdot 39- \\
2 \cdot 50)\end{array}$ \\
\hline $\begin{array}{l}\text { Freiberg, et al. } \\
\text { (CROI 2019, } \\
\text { unpublished) }\end{array}$ & $\begin{array}{c}\text { Veterans Aging Cohort } \\
\text { Study, USA }\end{array}$ & 144,336 & 43,407 & 3035 & $50(11)$ & $\begin{array}{c}\text { Sudden } \\
\text { cardiac death }\end{array}$ & Hazard ratio & $\begin{array}{c}1 \cdot 14(1 \cdot 04- \\
1 \cdot 25)\end{array}$ \\
\hline
\end{tabular}

\section{Classic Cardiovascular Risk Factors Related to HIV Patients}

Specific mechanisms that contribute to increased CVD include smoking, diabetes, dyslipidemia, hypertension and biological sex. As mentioned above, there are some regions in which exposure to any of these factors may be higher. In PLWH, lifestyle habits, such as the consumption of toxic substances such as tobacco, alcohol, cocaine, and a sedentary lifestyle, as well as the high frequency with which patients develop dyslipidemia and insulin resistance, play a recognized role in the development of cardiovascular disease in HIV-infected persons. All these factors and its higher intensity have a recognized role in the development of cardiovascular disease in PLWH [17]. Smoking rates among HIV-infected adults worldwide are generally higher than in the general population [18]. Drug addicts to parenteral lattes acquire hepatitis $\mathrm{C}$ and/or B in almost 80-90\%. Itś well known that infections in general, and for example Hepatitis C, are associated with an increased risk of cardiovascular disease [19]. In the case of hepatitis B, this association has not been proven [19]. Although controversial, CMV infection has been associated with an increased risk of CVD in the general population and with coronary atherosclerosis in cardiac transplant recipients. It is possible that CMV-associated immune responses play a key role in the development of atherosclerosis in personas living with HIV [20].

\section{Tools and Based CVD Prediction Models}

The increased CVD morbidity and mortality among HIVinfected patients warrants routine implementation of inexpensive and noninvasive risk assessment tools such as CVD risk estimation calculators. However, the predictability of existing, CVD risk calculators derived and generally validated in HIV-uninfected patient populations has been variable, with many studies suggesting they may inaccurately estimate CVD risk in HIV-infected patients.

\section{USA}

The United States has historically used the Framingham Risk Score (FRS), which was developed from the Framingham Heart Study, to predict individuals' 10 year risk of developing CHD. In 2013, the Atherosclerotic CVD (ASCVD) risk score derived from the Pooled Cohort Equation was developed by the American College of Cardiology and American Heart Association and has begun replacing the FRS [21]. The ASCVD risk score includes the variables in the FRS plus diabetes mellitus diagnosis or treatment.

\section{Europe}

There has been some widely used CVD prediction models derived in Europe as well. The United Kingdom utilizes the QRISK2 score to predict 10-year risk of CVD defined in this case as CHD, stroke and transient ischemic attack transient ischemic attack 
[22]. The Systematic Coronary Risk Evaluation (SCORE) is a risk estimator of 10 year fatal CVD derived from 12 European cohort studies mainly from general population settings [23]. Another tool was the Prospective Cardiovascular Münster (PROCAM) score was derived from a German cohort of industrial employees to predict risk of CVD [24].

Nonetheless, the various risk prediction models also share some similarities with significant overlap of predictive variables and derivation from high-income European countries or American cohorts. None of the CVD risk estimation tools described above were derived from HIV-infected populations, and therefore they may not adequately predict risk of developing CVD in HIV-infected patients. A CVD risk model for HIV-positive patients was derived from the D:A:D study by Friis-Møller, et al. The variables included in their model included: age, sex, systolic blood pressure, smoking status, family history of CVD, diabetes mellitus, total cholesterol, HDL-c, indinavir (IDV), lopinavir/ritonavir (LPV/r), and abacavir

Table 2.
(ABC) exposure. This model more accurately predicted observed MI, CHD, and CVD rates compared to FRS.

An interesting study compares Cardiovascular risk prediction scores in HIV-infected patients: the Framingham, atherosclerotic cardiovascular disease risk score (ASCVD), Systematic Coronary Risk Evaluation for the Netherlands (SCORE-NL) and Data Collection on Adverse Events of Anti-HIV Drugs (D:A:D) risk prediction models, and concluded that when using FHS-CVD and FHS-CHD, a higher overall CVD risk was attributed to the HIV-infected patients than when using the D:A:D, ASCVD and SCORE-NL models [25]. Depending on the population to be studied and until a new CVD risk assessment tool has been derived and validated in the HIV population, we are left to applying and choose between FRS, or the newer ASCVD risk score to HIV-infected patients [26] or the D:A:D cardiovascular disease risk score that has recently been updated to facilitate use in everyday clinical practice [27] (Table 2).

\begin{tabular}{|c|c|c|}
\hline ART & Observation & Reference \\
\hline \multirow{3}{*}{ NRTIs } & D: A:D study evaluated NRTI exposure and excess risk of MI & \multirow{3}{*}{$\begin{array}{l}\text { Sabin CA, Worm SW, Weber R, Reiss P, El Sadr W, et al. (2008) } \\
\text { Use of nucleoside reverse transcriptase inhibitors and risk } \\
\text { of myocardial infarction in HIV-infected patients enrolled in } \\
\text { the D:A:D study: a multi-cohort collaboration. The Lancet } \\
\text { 371(9622): } 1417-1426\end{array}$} \\
\hline & $\begin{array}{l}\text { >No association found between rate of MI and cumulative or } \\
\text { recent zidovudine, stavudine, or lamivudine use }\end{array}$ & \\
\hline & $\begin{array}{l}\text { >Recent-but not cumulative -abacavir or didanosine use was } \\
\text { associated with increase rate of MI }\end{array}$ & \\
\hline \multirow{3}{*}{ PIs } & Associated with IM in D: A:D study & \multirow{3}{*}{$\begin{array}{l}\text { Feinstein Matthew J, Hsue Priscilla Y, Benjamin Laura } \\
\text { A, Bloomfield Gerald S, Currier Judith S, et al. (2019) } \\
\text { Characteristics, Prevention, and Management of Cardiovascular } \\
\text { Disease in People Living With HIV: A Scientific Statement From } \\
\text { the American Heart Association. Circulation 140(2): e98-124. }\end{array}$} \\
\hline & $\begin{array}{l}>\text { Each year of cumulative PI use associated with } 10 \% \text { greatest } \\
\text { risk of MI, even after adjustment for cholesterol changes caused } \\
\text { by Pis }\end{array}$ & \\
\hline & $\begin{array}{c}\text { >Multiple reports shoe link between PIs and increase risk of MI, } \\
\text { including: }\end{array}$ & \\
\hline \multirow{3}{*}{ INIs } & Ritonavir, Indinavir, and fixed combination of lopinavir/ritonavir & $\begin{array}{l}\text { Palella FJJ, Phair JP (2011) Cardiovascular disease in HIV } \\
\text { infection. Current Opinion in HIV and AIDS 6(4): 266-271. }\end{array}$ \\
\hline & Database study of 20.459 patients initiated on ART & $\begin{array}{l}\text { O'Halloran JA, Dunne E, Tinago W, Denieffe S, Kenny D, et al. } \\
\text { (2018) Switching from abacavir to tenofovir disoproxil fumarate } \\
\text { is associated with rises in soluble glycoprotein VI, suggesting } \\
\text { changes in platelet-collagen interactions. AIDS 32(7): 861-866. }\end{array}$ \\
\hline & $\begin{array}{l}>\text { INI based regimens were associated with a } 43 \% \text { decreased risk } \\
\text { of CVD compared with non -INI based regimens }\end{array}$ & $\begin{array}{c}\text { O’Halloran JA, Sahrmann JM, Butler AM, Olsen MA, Powderly } \\
\text { WG (2019) Lower Cardiovascular Disease Risk Associated with } \\
\text { Integrase Inhibitors. CROI } 680 .\end{array}$ \\
\hline \multirow[b]{2}{*}{ NNRTIs } & Demonstrated to give rise to pro atherogenic serum lipid profiles & $\begin{array}{l}\text { Palella FJJ, Phair JP (2011) Cardiovascular disease in HIV } \\
\text { infection. Current Opinion in HIV and AIDS 6(4): 266-271. }\end{array}$ \\
\hline & $\begin{array}{c}\text { >Unclear increases seen in LDL-C reflected greated CVD risk } \\
\text { given that HDL-C also increases, and exposure is not associated } \\
\text { with greater risk of MI }\end{array}$ & $\begin{array}{l}\text { Baker Jason V, Sharma Shweta, Achhra Amit C, Bernardino } \\
\text { Jose Ignacio, Bogner Johannes R, et al. (2017) Changes in } \\
\text { Cardiovascular Disease Risk Factors With Immediate Versus } \\
\text { Deferred Antiretroviral Therapy Initiation Among HIV-Positive } \\
\text { Participants in the START (Strategic Timing of Antiretroviral } \\
\text { Treatment) Trial. Journal of the American Heart Association } \\
\text { 6(5): e004987. }\end{array}$ \\
\hline
\end{tabular}

\section{Mechanisms Related to HIV Infection}

The mechanisms involved in the proinflammatory effects in PLWH are directly related to the presence of human immunodeficiency virus [28]. The depletion of $\mathrm{T}$ lymphocytes increases intestinal permeability, altering lipid metabolism and favoring bacterial translocation [29]. CD4 depletion is associated with increased cardiovascular risk and a higher incidence of acute myocardial infarction, heart failure, peripheral artery disease, and ischemic stroke. This phenomenon is well studied, and several studies have shown that inflammatory biomarkers are elevated [30]. Many of these markers are known to be associated with atherogenesis and consequently with major cardiovascular events. 
Lipodystrophy may also be a contributing factor to increased cardiovascular risk due to metabolic changes. Lipodystrophy, which is an abnormal distribution of body fat, occurs as a result of HIV infection and, in fact, with some antiretroviral drugs. This fat change can be in the form of lipoacoumulo, with an increase in fat in the abdomen, breasts and/or buffalo hump, which remember the metabolic syndrome in the HIV-infected patient to show the same metabolic changes. It can also manifest as lipoatrophy, with loss of fat from the extremities and face. It is not uncommon for patients to have mixed lipodystrophy. Lipodystrophy is associated with dyslipidemia and insulin resistance [31].

\section{Atherosclerosis}

Atherosclerosis is considered a chronic inflammatory process. HIV infection is known that causes endothelial dysfunction. HIV infects smooth muscle cells in in vitro and in vivo studies and promotes secretion of inflammatory cytokines. The differences between atherosclerosis in patients without HIV and PLWH are morphological. Imaging studies confirm these differences [32]. Techniques such as ultrasound and computed tomographic angiography show a higher prevalence of hypogenic plaques and a higher incidence of CV events [33]. Using angiographic computed tomography, noncalcified plaques are more common and more extensive in HIV patients compared to control groups [34].

\section{Endothelial Disfunction and Novel Biomarkers}

Endothelial dysfunction is prevalent among HIV-infected patients despite successful administration of antiretroviral drugs. It is important to recognize that these are surrogate markers of subclinical disease that do not necessarily translate into observed CVD events [35]. Endothelial function could be measure with non invasive methods like blood-based biomarkers, such as endothelial leukocyte adhesion molecule-1 (E-selectin), soluble intercellular adhesion molecule-1 (sICAM-1), soluble vascular cell adhesion molecule-1 (sVCAM-1), von Willebrand factor (vWF), TNF- $\alpha$, interleukin 6 (IL6) and soluble thrombomodulin (sTM) [36]. Identification of appropriate blood biomarkers, especially those that can be measured by simple tests, would be more applicable in resource-poor countries where HIV prevalence is high [37]. In addition to mortality, higher circulating inflammatory markers are associated with contemporaneous insulin resistance or the future risk of diabetes in PLWH.

\section{Factors Associated with Antiretroviral Therapy}

The adverse effects of ART in CVD must be balanced against the beneficial effects of the therapy. Older ART regimens (e.g., abacavir, lopinavir and ritonavir) had adverse effects on glucose metabolism, lipids and mitochondrial toxicity. Weight gain after initiation of ART and viral suppression partly reflects the effects of viral suppression [38]. HIV patients undergoing cART exhibit a partial reversal of immune activation and inflammation. Additionally, cART reduces opportunistic infections and cardiovascular risk factors, which is likely a result of some reduction in inflammation, although residual markers of inflammation and coagulation remains elevated in ARTtreated HIV-infected patients.

There are currently 6 major groups of antiretroviral drugs. The scientific community has made many efforts to try to catalogue the cardiovascular risk of antiretroviral drugs. The impact of each on cardiovascular disease is difficult to assess for the following limitations:

a) It is necessary to combine two or three drugs to achieve viral suppression.

b) Continuous treatment reduces the risk, but some drugs alone increase this risk.

c) The increased risk due to ART would be mediated by abnormalities of lipid metabolism, other metabolic alterations are still poorly understood, such as coagulation alterations.

d) The increase in cardiovascular risk increases gradually with years of treatment.

e) The change from antiretroviral medication to less toxic ones makes it difficult to assess the real risk.

f) Follow-up is relatively short,

g) And at least ART history is unclear, and most do not have uninfected HIV controls.

Historically with the administration of ART and the emergence of protease inhibitors (PIs), cases of early atherosclerosis and myocardial infarction began to emerge in HIV-infected patients. The temporal relationship between these facts suggested some causality. The possible cardiovascular effect of these early PIs (nelfinavir or ritonavir in high doses) was mainly because they caused significant metabolic and fatty changes. Since then, new drugs and even new therapeutic targets have emerged. Current antiretroviral therapy generally requires a combination of three or two active drugs $[39,40]$ for sustained control of HIV replication and avoid resistance.

Until now the largest prospective cohort study that compiles data on adverse effects of anti-HIV drugs (the DAD study with more than 23.000 consecutive patients), the incidence of myocardial infarction is low (3.5 cases per 1.000 person-years), and conventional cardiovascular risk factors show a higher relative contribution to the development of myocardial infarction than PI exposure. In this study, the relative risk attributable to PIs (16\% increase in risk of drug exposure per year) was halved after adjustment for increases in total cholesterol and decreases in HDL cholesterol, suggesting that a substantial portion of the risk attributable to PIs cannot be explained solely by lipid changes. The DAD cohort evaluated the contribution of each NRTI to the risk of 
myocardial infarction, and the results were surprising. Contrary to expectations, patients taking thymidine analogue inhibitors were not associated with increased cardiovascular risk, despite their contribution to dyslipidemia, insulin resistance, and lipoatrophy. Surprisingly, exposure to abacavir or didanosine in the past 6 months was associated with a $90 \%$ and $50 \%$ increased risk of myocardial infarction, respectively, after adjustment for several cardiovascular factors. Interestingly, the excess risk as described by the authors quickly disappears after treatment. The relative risk associated with these patients was higher in those with high cardiovascular risk [41].

Also, in the SMART study (Strategies for Management of Antiretroviral Therapy) [42], the episodic use of ART was compared with continuous ART. During 16 months of follow up, the episodic use of ART was associated with an increased risk of death and opportunistic infections including an increase in CV events. Inflammatory and coagulation biomarkers in SMART, namely IL-6 and D-Dimer, were strongly related to all-cause mortality, suggesting that this was the mechanism whereby intermittent ART increased the risk [43]. In the SMART study, the use of abacavir (but not didanosine) is associated with excess risk of myocardial infarction and other cardiovascular events. The increased risk is not due to lipid changes, according to both studies. Researchers found higher levels of inflammatory markers in patients taking abacavir than in those who did not, suggesting a potential fire mechanism. Another alternative for pathogenesis speculates that abacavir may interfere with the proinflammatory signaling molecules tri-adenosine

Table 3
(ATP) and diphosphate (ADP) present in vascular endothelial cells [44]. No definitive conclusions can be drawn from the currently available data. The fact that abacavir is associated with an excess risk of myocardial infarction according to the DAD cohort does not necessarily imply that abacavir plays a causal role.

Further clinical trials and laboratory studies will be needed to determine any causal role of abacavir or didanosine in the development of cardiovascular disease [45]. Although earlier protease inhibitors have been associated with increased risk of cardiovascular disease, whether this increased risk also applies to more contemporary protease inhibitors is unknown $[46,47]$. A different group of ART, NNRTI, shows superior cardiovascular profile compared with the PI family in clinical trials. Results are not limited exclusively to a higher increase in HDL cholesterol, but also to a decrease in procoagulant markers and to lower oxidative stress. Other recent studies with integrase inhibitors suggest that dyslipidemia was less common in patients treated with INSTI regime. Dyslipidemia was less common with INSTI than with PI/b. Compared with dolutegravir, dyslipidemia was more common with elvitegravir/cobicistat and raltegravir, but less common with rilpivirine [48]. Other study's shows that the risk of CVD in PLWH on INSTI-based regimens were associated with a $43 \%$ decreased risk of CVD. Authors agree that validation of these findings in cohorts with longer follow up is needed [49] (Table 3). Aging patients with HIV [50], like the general population, tend to have polypharmacy, which increases drug interactions and consequent adverse reactions.

\begin{tabular}{|c|}
\hline Assessing CV Risk and Metabolic Disorders to Individualize Therapy \\
\hline 1. No specific risk equation for PLWH, other than D:A:D risk equation (a) \\
\hline 2. Current equation can underestimate risk in PLWH (a) \\
\hline 3. Can use traditional CV risk factors, or AHA/ACC pooled cohort equation (b) \\
\hline >Includes age, diabetes, smoking, HTN, dyslipidemia \\
\hline >ASCVD risk enhances in HIV identified in 2018 ACC/AHA cholesterol clinical practice guidelines include: \\
\hline 1) History of prolonged HIV viremia and/or delay in ART initiation \\
\hline 2) Low current or nadir CD4 count ( $<350$ cells/mm32) \\
\hline 3) HIV treatment failure or non-adherence \\
\hline 4) Metabolic syndrome, lipodystrophy/lipoatrophy, fatty liver disease \\
\hline 5) HCV co-infection \\
\hline $\begin{array}{l}\text { a) Serrano Villar S, Estrada V, Gómez Garre D, Ávila M, Fuentes Ferrer M, et al. (2014) Diagnosis of subclinical atherosclerosis in HIV-infected patients: } \\
\text { higher accuracy of the D:A:D risk equation over Framingham and SCORE algorithms. European Journal of Preventive Cardiology 21(6): 739-748. }\end{array}$ \\
\hline $\begin{array}{l}\text { b) Feinstein Matthew J, Hsue Priscilla Y, Benjamin Laura A, Bloomfield Gerald S, Currier Judith S, et al. (2019) Characteristics, Prevention, and } \\
\text { Management of Cardiovascular Disease in People Living With HIV: A Scientific Statement From the American Heart Association. Circulation } 140(2) \text { : } \\
\text { e98-124. }\end{array}$ \\
\hline
\end{tabular}

\section{Insulin Resistance and ART}

It is generally accepted that there is a correlation between innate immune system activation and insulin resistance, which contributes to glucose metabolism dysregulation and dyslipidemia. However, untreated HIV-patients display an enhanced inflammatory state, which is characterized by high levels of proinflammatory cytokines, like tumor necrosis factor alpha (TNF- $\alpha$ ), and interleukins (IL6 and IL-1 $\beta$ ) and is associated with a procoagulant state. Under these conditions, the insulin resistance is probably severe and could occur in the liver, muscle, and adipose tissue. In fact, severe 
insulin resistance in the adipose tissue (as observed in HIV untreated patients), may prevents adipose mass gain as described in mice [51]. Protease inhibitors (PI) or nucleoside analog reverse transcriptase inhibitors (NRTI) have been shown to induce insulin resistance, dyslipidemia, and lipodystrophy, and consequently increase cardiovascular risk [52]. Insulin resistance can be caused by specific in vitro drugs, including indinavir and other firstgeneration IPs. Clinical trials that initiate treatment with different long-term PIs (such as lopinavir/ritonavir, saquinavir/ritonavir, or tipranavir/ ritonavir), moreover, do not show significant changes in insulin sensitivity when the ART regimen does not include NRTIs. Thymidine analogous (NRTIs) such as stavudine and zidovudine, have been associated with increased insulin resistance in healthy volunteers; similarly, didanosine or thymidine analogues have been described in large cohort studies of HIV-infected patients to confer an increased risk of diabetes mellitus (Table 4).

Table 4.

\begin{tabular}{|c|c|}
\hline \multicolumn{2}{|c|}{ The Effect of HIV and ART on Cardiometabolic Health } \\
\hline PLWH have: & ART can cause \\
\hline $\begin{array}{c}\text { Higher Risk of Traditional Risk } \\
\text { Factors }\end{array}$ & Dyslipidemia \\
\hline Dyslipidemia & Insulin resistance \\
\hline Metabolic disease & Lipodystrophy \\
\hline Smoking & Cardiometabolic syndrome \\
\hline \multicolumn{2}{|l|}{ HTN } \\
\hline \multicolumn{2}{|l|}{ Substance use } \\
\hline $\begin{array}{l}\text { Higher Rate of Metabolic } \\
\text { Complications }\end{array}$ & \multirow{4}{*}{$\begin{array}{l}\text { Chronic inflammation, HIV- } \\
\text { related viremia, and immune } \\
\text { dysfunction are associated } \\
\text { with higher MI risks }\end{array}$} \\
\hline Dyslipidemia & \\
\hline Insulin resistance & \\
\hline Body composition changes & \\
\hline \multicolumn{2}{|l|}{ Chronic inflammation } \\
\hline Immune activation & \\
\hline
\end{tabular}

\section{Conclusion}

The absolute risk of cardiovascular disease in HIV-infected patients on antiretroviral therapy is low. However, this risk of cardiovascular disease in HIV-infected patients is higher compared with uninfected individuals. This is due, at least in large part, to the higher prevalence of classic cardiovascular risk factors. In addition, HIV infection may contribute to this risk through immunological activation, inflammation and immunodeficiency. Also, although compared with HIV infections, the type of antiretroviral therapy may contribute to increased cardiovascular risk, primarily through metabolic changes, body-level changes, and other factors that are currently unclear. From a purely cardiovascular perspective, the benefits of antiretroviral therapy outweigh the potential risks. A big field in PLWH is the prevention of major cardiovascular events (MACE). Since HIV is becoming a chronic disease, it is necessary to think about prevention of cardiovascular disease. Starting from the basics such as education of good alimentary habits, physical activity, reducing alcohol and treating drug consumption.

In outpatients it's necessary to control blood pressure values, the lipid profile, and have EKG recordings. Stress testing, echocardiography, cardiac magnetic resonance, and radionuclide imaging are also effective methods to identify patients who have less coronary reserve $[53,54]$. Currently, there are programs that allow warning of drug interactions. The treating physician should prevent possible adverse interactions by looking for alternatives in therapy. As can be seen, a complex and complete approach is required in the HIV patient. PLWH are not the same patients of 30 years ago when the main goal was practically to avoid opportunistic infections in patients already diagnosed late. As the morbidity and mortality from CVD in the HIV population increases, so too must preventive and therapeutic efforts to provide these patients with the best care. This all begins with accurate CVD risk assessment.

\section{References}

1. Samji H, Cescon A, Hogg RS, Modur SP, Althoff KN, et al. (2013) Closing the Gap: Increases in Life Expectancy among Treated HIV-Positive Individuals in the United States and Canada. PLOS ONE 8(12): e81355.

2. Brouillette J, Cyr S, Fiset C (2019) Mechanisms of Arrhythmia and Sudden Cardiac Death in Patients With HIV Infection. Canadian Journal of Cardiology 35(3): 310-319.

3. Feinstein Matthew J, Hsue Priscilla Y, Benjamin Laura A, Bloomfield Gerald S, Currier Judith S, et al. (2019) Characteristics, Prevention, and Management of Cardiovascular Disease in People Living With HIV: A Scientific Statement From the American Heart Association. Circulation 140(2): e98-124.

4. Behrens G, Schmidt H, Meyer D, Stoll M, Schmidt RE (1998) Vascular complications associated with use of HIV protease inhibitors. The Lancet 351(9120): 1958

5. Rasmussen LD, Omland LH, Pedersen C, Gerstoft J, Kronborg G, et al. (2010) Risk of myocardial infarction in parents of HIV-infected Individuals: a population-based Cohort Study. BMC Infect Dis 10: 169.

6. Abdelazeem B, Gergis K, Baral N, Rauniyar R, Adhikari G (2021) Sudden Cardiac Death and Sudden Cardiac Arrest in Patients with Human Immunodeficiency Virus: A Systematic Review. Cureus 13(3): e13764.

7. Monreal E, Gullón P, Pérez Torre P, Escobar Villalba A, Acebron F, et al. (2020) Increased HIV infection in patients with stroke in Spain. A 16year population-based study. Enfermedades Infecciosas y Microbiología Clínica 38(5): 219-225.

8. Hsue PY, Waters DD (2017) Heart failure in persons living with HIV infection. Current Opinion in HIV and AIDS 12(6): 534-539.

9. Paraskevas KI, Katsiki N, Tzovaras AA, Koupidis SA, Mikhailidis DP (2011) Peripheral Arterial Disease and HIV-Positive Patients. Angiology 62(1): 7-9.

10. Hsue Priscilla Y, Waters David D (2018) Time to Recognize HIV Infection as a Major Cardiovascular Risk Factor. Circulation 138(11): 1113-1115.

11. Kelly SG, Plankey M, Post WS, Li X, Stall R, et al. (2016) Associations between Tobacco, Alcohol, and Drug Use with Coronary Artery Plaque among HIV-Infected and Uninfected Men in the Multicenter AIDS Cohort Study. PLOS ONE 11(1): e0147822.

12. Naidu S, Ponnampalvanar S, Kamaruzzaman SB, Kamarulzaman A (2017) Prevalence of Metabolic Syndrome Among People Living with HIV in Developing Countries: A Systematic Review. AIDS Patient Care 
and STDs 31(1): 1-13.

13. Herrin M, Tate JP, Akgün KM, Butt AA, Crothers K, et al. (2016) Weight Gain and Incident Diabetes Among HIV-Infected Veterans Initiating Antiretroviral Therapy Compared With Uninfected Individuals. JAIDS Journal of Acquired Immune Deficiency Syndromes 73(2): 228-236.

14. Maggi P, Di Biagio A, Rusconi S, Cicalini S, D’Abbraccio M, et al. (2017) Cardiovascular risk and dyslipidemia among persons living with HIV: a review. BMC infectious diseases 17(1): 551-551.

15. Rezaei S, Ahmadi S, Rahmati J, Hosseinifard H, Dehnad A, et al. (2019) Global prevalence of depression in HIV/AIDS: a systematic review and meta-analysis. BMJ Supportive \& Palliative Care 9(4): 404-412.

16. Shah Anoop SV, Stelzle Dominik, Lee Kuan Ken, Beck Eduard J, Alam Shirjel, et al. (2018) Global Burden of Atherosclerotic Cardiovascular Disease in People Living With HIV. Circulation 138(11): 1100-1112.

17. Palella FJJ, Phair JP (2011) Cardiovascular disease in HIV infection Current Opinion in HIV and AIDS 6(4): 266-271.

18. De Socio GV, Pasqualini M, Ricci E, Maggi P, Orofino G, et al. (2020) Smoking habits in HIV-infected people compared with the general population in Italy: a cross-sectional study. BMC Public Health 20(1): 734.

19. Vassalle C, Masini S, Bianchi F, Zucchelli GC (2004) Evidence for association between hepatitis $\mathrm{C}$ virus seropositivity and coronary artery disease. Heart 90(5): 565-566

20. Wang Haoran, Peng Geng, Bai Jing, He Bing, Huang Kecheng, et al. (2017) Cytomegalovirus Infection and Relative Risk of Cardiovascular Disease (Ischemic Heart Disease, Stroke, and Cardiovascular Death): A MetaAnalysis of Prospective Studies Up to 2016. Journal of the American Heart Association 6(7): e005025.

21. Goff DC, Lloyd Jones DM, Bennett G, Coady S, D’Agostino RB, et al. (2014) 2013 ACC/AHA Guideline on the Assessment of Cardiovascular Risk: A Report of the American College of Cardiology/American Heart Association Task Force on Practice Guidelines. Journal of the American College of Cardiology 63(25 Pt B): 2935-2959.

22. Hippisley Cox J, Coupland C, Vinogradova Y, Robson J, Minhas R, et al. (2008) Predicting cardiovascular risk in England and Wales: prospective derivation and validation of QRISK2. BMJ 336(7659): 1475-1482.

23. Conroy RM, Pyörälä K, Fitzgerald AP, Sans S, Menotti A, et al. (2003) Estimation of ten-year risk of fatal cardiovascular disease in Europe: the SCORE project. Eur Heart J 24(11): 987-1003.

24. Assmann Gerd, Cullen Paul, Schulte Helmut (2002) Simple Scoring Scheme for Calculating the Risk of Acute Coronary Events Based on the 10-Year Follow-Up of the Prospective Cardiovascular Münster (PROCAM) Study. Circulation 105(3): 310-315.

25. Krikke M, Hoogeveen RC, Hoepelman AIM, Visseren FLJ, Arends JE (2016) Cardiovascular risk prediction in HIV-infected patients: comparing the Framingham, atherosclerotic cardiovascular disease risk score (ASCVD), Systematic Coronary Risk Evaluation for the Netherlands (SCORE-NL) and Data Collection on Adverse Events of Anti-HIV Drugs (D:A:D) risk prediction models. HIV Medicine 17(4): 289-297.

26. Thompson Paul AM, Lichtenstein KA, Armon C, Palella FJ, Skarbinski J, et al. (2016) Cardiovascular Disease Risk Prediction in the HIV Outpatient Study. Clinical Infectious Diseases 63(11): 1508-1516.

27. Friis Møller N, Ryom L, Smith C, Weber R, Reiss P, et al. (2016) An updated prediction model of the global risk of cardiovascular disease in HIV-positive persons: The Data-collection on Adverse Effects of Anti-HIV Drugs (D:A:D) study. European Journal of Preventive Cardiology 23(2): 214-223.

28. Hsue PY (2019) Mechanisms of Cardiovascular Disease in the Setting of HIV Infection. Canadian Journal of Cardiology 35(3): 238-248.
29. Brenchley JM, Price DA, Schacker TW, Asher TE, Silvestri G, et al. (2006) Microbial translocation is a cause of systemic immune activation in chronic HIV infection. Nature Medicine 12(12): 1365-1371.

30. Neuhaus J, Jacobs DR, Baker JV, Calmy A, Duprez D, et al. (2010) Markers of Inflammation, Coagulation, and Renal Function Are Elevated in Adults with HIV Infection. The Journal of Infectious Diseases 201(12): 17881795.

31. Grunfeld C, Saag M, Cofrancesco JJ, Lewis CE, Kronmal R, et al. (2010) Regional adipose tissue measured by MRI over 5 years in HIV-infected and control participants indicates persistence of HIV-associated lipoatrophy. AIDS 24(11): 1717-1726.

32. Boldeanu I, Sadouni M, Mansour S, Baril JG, Trottier B, et al. (2021) Prevalence and Characterization of Subclinical Coronary Atherosclerotic Plaque with CT among Individuals with HIV: Results from the Canadian HIV and Aging Cohort Study. Radiology 299(3): 571-580.

33. Peyracchia M, De Lio G, Montrucchio C, Omedè P, d'Ettore G, et al. (2018) Evaluation of coronary features of HIV patients presenting with ACS: The CUORE, a multicenter study. Atherosclerosis 274: 218-26.

34. Post WS, Budoff M, Kingsley L, Palella FJ, Witt MD, et al. (2014) Associations Between HIV Infection and Subclinical Coronary Atherosclerosis. Ann Intern Med 160(7): 458-467.

35. Haissman JM, Haugaard AK, Knudsen A, Kristoffersen US, Seljeflot I, et al. (2016) Marker of Endothelial Dysfunction Asymmetric Dimethylarginine Is Elevated in HIV Infection but Not Associated With Subclinical Atherosclerosis. JAIDS Journal of Acquired Immune Deficiency Syndromes 73(5): 507-513.

36. Vos AG, Idris NS, Barth RE, Klipstein Grobusch K, Grobbee DE (2016) Pro-Inflammatory Markers in Relation to Cardiovascular Disease in HIV Infection. A Systematic Review. PLOS ONE 11(1): e0147484.

37. Mezoh G, Crowther NJ (2019) Deciphering Endothelial Dysfunction in the HIV-Infected Population. In: Guest PC, (Edi.). Reviews on Biomarker Studies of Metabolic and Metabolism-Related Disorders, pp. 193-215.

38. El Sadr WM, Lundgren JD, Neaton JD, Gordin F, Abrams D, et al. (2006) CD4+ Count-Guided Interruption of Antiretroviral Treatment. New England Journal of Medicine 355(22): 2283-2296.

39. Diaco ND, Strickler C, Giezendanner S, Wirz SA, Tarr PE (2018) Systematic De-escalation of Successful Triple Antiretroviral Therapy to Dual Therapy with Dolutegravir plus Emtricitabine or Lamivudine in Swiss HIV-positive Persons. EClinicalMedicine 6: 21-25.

40. Pisaturo M, Onorato L, Russo A, Martini S, Chiodini P, et al. (2021) Risk of failure in dual therapy versus triple therapy in naïve HIV patients: a systematic review and meta-analysis. Clinical Microbiology and Infection 27(1): 28-35.

41. Sabin CA, Worm SW, Weber R, Reiss P, El Sadr W, et al. (2008) Use of nucleoside reverse transcriptase inhibitors and risk of myocardial infarction in HIV-infected patients enrolled in the D:A:D study: a multicohort collaboration. The Lancet 371(9622): 1417-1426.

42. Baker Jason V, Sharma Shweta, Achhra Amit C, Bernardino Jose Ignacio, Bogner Johannes R, et al. (2017) Changes in Cardiovascular Disease Risk Factors With Immediate Versus Deferred Antiretroviral Therapy Initiation Among HIV-Positive Participants in the START (Strategic Timing of Antiretroviral Treatment) Trial. Journal of the American Heart Association. 6(5): e004987.

43. Kuller LH, Tracy R, Belloso W, Wit SD, Drummond F, et al. (2008) Inflammatory and Coagulation Biomarkers and Mortality in Patients with HIV Infection. PLOS Medicine 5(10): e203.

44. Groups TS, DS (2008) Use of nucleoside reverse transcriptase inhibitors and risk of myocardial infarction in HIV-infected patients. AIDS 22(14): F17-24. 
45. Llibre JM, Hill A (2016) Abacavir and cardiovascular disease: A critical look at the data. Antiviral Research 132: 116-121.

46. Ryom L, Lundgren JD, El Sadr W, Reiss P, Kirk O, et al. (2018) Cardiovascular disease and use of contemporary protease inhibitors: the D:A:D international prospective multicohort study. The Lancet HIV 5(6): e291-300.

47. Sun D, Wu Y, Yuan Y, Wang Y, Liu W, et al. (2015) Is the atherosclerotic process accentuated under conditions of HIV infection, antiretroviral therapy, and protease inhibitor exposure? Meta-analysis of the markers of arterial structure and function. Atherosclerosis 242(1): 109-116.

48. Group TRS (2021) Incidence of dyslipidemia in people with HIV who are treated with integrase inhibitors versus other antiretroviral agents. AIDS 35(6): 869-882

49. O’Halloran JA, Sahrmann JM, Butler AM, Olsen MA, Powderly WG (2019) Lower Cardiovascular Disease Risk Associated with Integrase Inhibitors. CROI 680.

\section{ISSN: 2574-1241}

DOI: 10.26717/BJSTR.2021.36.005808

Ricardo Massmann. Biomed J Sci \& Tech Res

(c) (P) This work is licensed under Creative

Submission Link: https://biomedres.us/submit-manuscript.php
50. Guaraldi G, Milic J, Mussini C (2019) Aging with HIV. Curr HIV/AIDS Rep 16(6): 475-481.

51. Blüher M, Kahn BB, Kahn CR (2003) Extended Longevity in Mice Lacking the Insulin Receptor in Adipose Tissue. Science 299(5606): 572-574.

52. Willig AL, Overton ET (2016) Metabolic Complications and Glucose Metabolism in HIV Infection: A Review of the Evidence. Curr HIV/AIDS Rep 13(5): 289-296.

53. Thompson MA, Horberg MA, Agwu AL, Colasanti JA, Jain MK, et al. (2020) Primary Care Guidance for Persons With Human Immunodeficiency Virus: 2020 Update by the HIV Medicine Association of the Infectious Diseases Society of America. Clinical Infectious Diseases, ciaa1391.

54. Serrano Villar S, Estrada V, Gómez Garre D, Ávila M, Fuentes Ferrer M, et al. (2014) Diagnosis of subclinical atherosclerosis in HIV-infected patients: higher accuracy of the D:A:D risk equation over Framingham and SCORE algorithms. European Journal of Preventive Cardiology 21(6): 739-748.

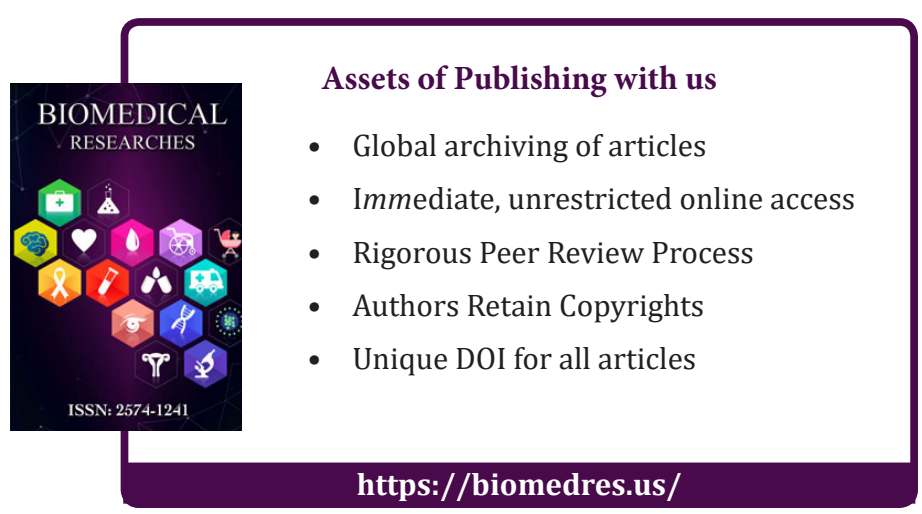

